puration described. Again, in the section on treatment of tuberculous disease of the larynx no mention is made of injections of alcohol for dysphagia, nor of the use of the cautery, nor of the use of tuberculin. These are but a few of numerous omissions which we have noticed in reading this work. The general appearance of the book and the printing is all that can be desired.

\title{
Lang's German-English Dictionary of Terms Used in Medicine and the
} Allied Sciences. Second Edition, Edited and Revised, by Milton K. Meyers, M.D. Pp. viii. +564. London : J. \& A. Churchill. 1913. Price 18s. net.

In this compendious dictionary there are nearly 50,000 entries, the additions made since the first edition was issued numbering 4400 . It is thus a very comprehensive and useful aid to the English student of German medical literature. In glancing through its pages we noted a few inaccuracies and omissions, and have no hesitation in pointing these out in view of the likelihood of further editions being called for. Schwerverdaulichkeit is rendered "dyspepsia" instead of indigestibility. Heine-medinsche Krankheit is translated as "spastic spinal paralysis of infancy," whereas it is the name of acute poliomyelitis or "infantile paralysis." On the other hand, Little'sche Krankheit, or cerebral diplegia, is omitted, as also is Werdnig-Hoffman-sche Krankheit. We venture to draw particular attention to these, because it is claimed in the preface that special care has been taken "in the rendering of those diseases and symptoms to which in German personal names are applied." Turning to some omissions we noted that decubitus, meaning a pressure ulcer or bedsore; dekomposition, marasmus; milchnährschaden, milk injury; bilanz-störung, weight disturbance; oxypathie, a diathesis of childhood; parenteral, signifying non-intestinal ; abreagiren, to abreact, in Freud's nomenclature, are not to be found. We are well aware that the facility with which new words can be coined in German renders it impossible that any dictionary can give all that are in use. Still, those which we mention have all passed into currency, and ought not to be left out of a dictionary. We would not have it thought, however, that these criticisms are intended in any way as aspersions on Dr. Meyer's work. On the contrary, it is only because his lexicon is so complete and extensive that we troubled to seek in it for flaws.

\section{NOTES ON BOOKS.}

The Healthy Marriage, by G. T. Wrench, M.D., Past Assistant-Master of the Rotunda Hospital, Dublin (Churchill, price 3s. 6d.), deals with many delicate problems with discrimination, sense, and reserve. It is a useful book.

The series of "National Insurance Prescriptions " which have already appeared in The Prescriber have now been issued as a booklet from the 
offices of the journal at the modest price of sixpence. Prescriptions containing drugs not included in the official tariff are starred. The list is well chosen and should prove useful.

\section{ANALYTICAL REPORTS. \\ "Enule" "Epinine" Suppositories. \\ (Burroughs Wellcome \& Co.)}

AN "enule" suppository containing $\frac{1}{6}$ grain of "epinine " has been added to their list by Messrs. Burroughs Wellcome \& Co. The use of this synthetic hæmostatic, which resembles in its action the active principle of suprarenal gland, has been suggested as a suitable procedure, pending operative interference, in cases of hæmorrhoids, cancer of the rectum accompanied by hæmorrhage, and similar conditions. The normal dose, $0 \cdot 01 \mathrm{grm}$. ( $\frac{1}{6} \mathrm{gr}$.), being evenly diffused throughout the mass of the suppository, provides a local vasoconstrictor action without unduly raising the blood-pressure throughout the body. Like all "enule" suppositories, this product is of a special shape, with a bulbous end, which renders its administration and retention in situ easy and certain.

\section{Phosphocose. \\ (The Bayer Co., Ltid.)}

This is a new preparation of somatose, to which glycerophosphate is added. It forms a syrupy fluid with a pleasant taste and flavour, and is an excellent nerve food tonic. As it contains no alcohol or other preservative, and is sent out sterilised, it must be prescribed in the original bottle.

\section{VITAFER.}

(Southhall Brothers \& Barclay.)

Vitafer is one of the class of tonic foods which are at present so popular. It consists of milk protein and the glycerophosphates of calcium, sodium, and magnesium. The absence of nucleo-proteins is claimed as an advantage in arthritic patients, while the absence of carbohydrates renders it suitable in cases of diabetes. The glycerophosphates are readily assimilated, while the rather high proportion of the magnesium salt $(2 \cdot 2$ per cent.) obviates any tendency to constipation. There is no doubt that preparations containing phosphorus and casein in a readily digestible form are well borne by most persons, and that benefit follows their use in many forms of debility and malnutrition. Vitafer is a British product, and is moderate in price, so that it has extrinsic merit as well as intrinsic value. We believe that it will be found useful as an adjuvant in the treatment of many diseases.

\section{B. B. M. Flour.}

\section{(Argill Milina Co., Glasgow.)}

There is no doubt, we suppose, that a whole-meal flour has many points of superiority over ordinary flour. For this reason we venture to predict that the demand for flour such as the sample before us will increase. B. B. M. flour is a pure flour, ground by the old milling-stones, and it contains, therefore, a large proportion of protein and mineral matters. Phosphates are present to the extent of 0.45 per cent., while in ordinary white flour they amount only to about 0.06 per cent. It is desirable that such flour as this, which is not bleached by nitrogen peroxide, should be more widely used as a food stuff. 